\title{
Environmental assessment of organising: towards a framework for the study of organisational influence on environmental performance
}

\section{Henrikke Baumann}

Environmental Systems Analysis, Chalmers University of Technology, 41296 Göteborg, Sweden

E-mail: henrikke.baumann@esa.chalmers.se

\begin{abstract}
The paper discusses a new perspective on industry's environmental performance and presents the concept and field of environmental assessment of organising. EAO builds on the notion that different ways of managing industrial production lead to different environmental performance. To understand how industrial organising influences environmental performance it is necessary to take ordinary physical flow modelling of technical systems, such as life cycle assessment, a step further by embedding these in an organisational context. Such an understanding could provide new knowledge for environmentally 'smarter' management. The concept of EAO aims towards a theoretical framework that bridges environmental management, organisational theory and environmental systems analysis. Its presentation here is grounded in a literature review on works related to industrial environmental performance. Two studies testing the practical application of EAO are briefly presented and discussed. These have contributed to the presented basic methodology and rudimentary research programme for EAO studies.
\end{abstract}

Keywords: environmental performance; industrial systems; organisational theory; environmental management.

Reference to this paper should be made as follows: Baumann, H. (2004) 'Environmental assessment of organising: towards a framework for the study of organisational influence on environmental performance', Progress in Industrial Ecology, Vol. 1, Nos. 1/2/3, pp.292-306.

Biographical notes: Henrikke Baumann is an Assistant Professor at Environmental Systems Analysis at Chalmers University of Technology in Sweden. She has been working with life cycle assessment and related environmental tools since 1991. Her research combines an interest in the application and role of environmental tools with the preconditions for management of environmental issues in industry. Her combination of environmental analysis of technical systems and the management sciences has been central for the building up of competence on factors shaping industry's environmental work at the department, where she supervises a group of doctoral students in this interdisciplinary field. Ongoing projects include e.g. a survey of environmental attitudes and management in the building industry, environmental assessment of housing management and evaluations of LCA-related work in the pulp and paper industry. As a consequence, her research involves collaboration with management and organisation scholars as well as with industry.

Received September 13, 2003, Revised January 7, 2004, Accepted January 15, 2004

Copyright @ 2004 Inderscience Enterprises Ltd. 


\section{An enlightening view on management and environmental performance}

I work at a university department where life cycle assessment, both studies and methodology development, has been a core activity since 1991. Working with LCA, exploring the industrial systems behind different products has been very interesting. LCA studies uncover the often immense industrial network involved in the production of even simple products. Yet I have found LCAs somewhat unsatisfactory since products, in themselves, are not active parties in society. Instead, it is in the social and business context of the products where action, decision and change take place. The relationship between environment and management has been on my mind for some time and I have been looking for a way to go beyond the technical environmental analysis that LCA represent. Since few years back I have been toying with an idea of how to study that relationship. For the time being, I call this concept EAO, environmental assessment of organising.

The idea came to me on my way home from work. I live in on the top floor of an old five-storey apartment building, situated on the corner of a block. One evening, when pausing on the way up the 107 steps I looked out the window across the inner yard over to the neighbouring building and realised something. Although the two buildings were built in exactly the same way back in 1903, several technical characteristics had come to differ over the years: the existence of additional insulation or not, double or triple glazing in the windows, etc. These technical differences could be derived from the fact that the two buildings had had different ownership and property management for many years. What I realised was that environmental performance clearly depended on the management of the buildings and that the different technical changes to the buildings could be seen as expressions of different management practices and decisions in the two housing organisations.

The basic notion of the revelation on the stairway is that different ways of managing industrial production lead to different environmental performance. In other words, environmental performance does not depend solely on technology but also on the management of the technology. It led me to further think about the importance of organisation and management to environmental performance: how much was known about the relationship between organisations and their environmental performance? To what extent is environmental performance determined by technology or other factors such as economy, policy, management? Is it even possible to study such an intricate relationship as that between complex industrial organisational networks and the physical environment? If so, it would be interesting to find out how different organising principles and managerial strategies differ with regard to their environmental performance so that we may achieve environmentally 'smarter' management.

\section{The potential for greater efficiency}

There is literature that reports that the potential for greater efficiency may be greater than one would perhaps expect. Azar and Lindgren [1] explored the potential for greater energy efficiency in their study of the future energy consumption in Sweden. According to them, relatively conservative estimates indicate that there is a great potential for 
improving energy efficiency with known technology. For transportation, an efficiency improvement between $30 \%$ and $70 \%$ is possible depending on the type of transportation; for buildings, between $30 \%$ and $55 \%$ depending on the type of building and its fittings; for industry between $30 \%$ and $65 \%$ depending on the sector. However, the mere existence of a potential for greater efficiency is not enough to produce improvement. Azar and Lindgren [1] conclude that there are no technical or economic obstacles in the way for achieving greater efficiency since technology already is available (for similar examples in the USA, see [2]). Here I find support for the idea of looking into the organisational dimension to identify the obstacles to greater efficiency.

Explicit environmental management efforts can be suspected to not be as effective as they could be. Firms often deal with environmental issues through implementing environmental management systems. These are usually limited to site-level operational issues, and there is little publicly available information on their environmental effectiveness. Some studies indicate that they may not have a significant impact on environmental performance (e.g. [3-5]). Besides operational management, there are many other aspects of management and organisation that can influence environmental performance (e.g., scale of production, integration or distribution of productive activities, siting, choice of technology and strategy, governance). There have been calls to extend the scope of environmental management systems to broader issues, such as investments, strategy formulation and product development. And, as companies, other organisations and policy-makers proceed in their environmental work, they will need a more comprehensive understanding on which aspects of the organisation have an impact on the natural environment. These trends support attempts to characterising aspects of environmentally smarter management.

\section{Examples of varying environmental performance}

Organisation and management do seem to have considerable influence on environmental performance. Oblique evidence for this can be found in the literature. An example that shows how much the environmental impact can vary for a single type of product (see Figure 1) may serve as illustration of the importance of the organisational and managerial dimension. Scott Paper used life cycle assessment (LCA) to compare their 40 pulp suppliers. The comparison showed that carbon dioxide emissions (per tonne pulp) varied by more than a factor 100 [6]. Although all the suppliers deliver pulp for paper tissue, the environmental performance differed widely. Basic pulp production technology is in principle quite similar wherever it takes place - all the suppliers delivered the same type of pulp for paper tissue. The technological difference between the suppliers' pulp production, differences in energy sources, or discrepancies in LCA calculations are not great enough to account for the whole variation. Thus, there must be differences in the organising of the pulp production and distribution in order to account for the large variation. This includes the way companies in the product chain operate, maintain and manage their systems as well as how they relate to environmental regulation. 
Figure $1 \mathrm{CO}_{2}$ emissions for 40 pulp suppliers. In 1992, Scott Ltd benchmarked their 40 pulp suppliers. Using LCA methodology, emissions for pulp manufacturing from 'cradle-to-gate' were collected. The differences turned out to be staggering [6].

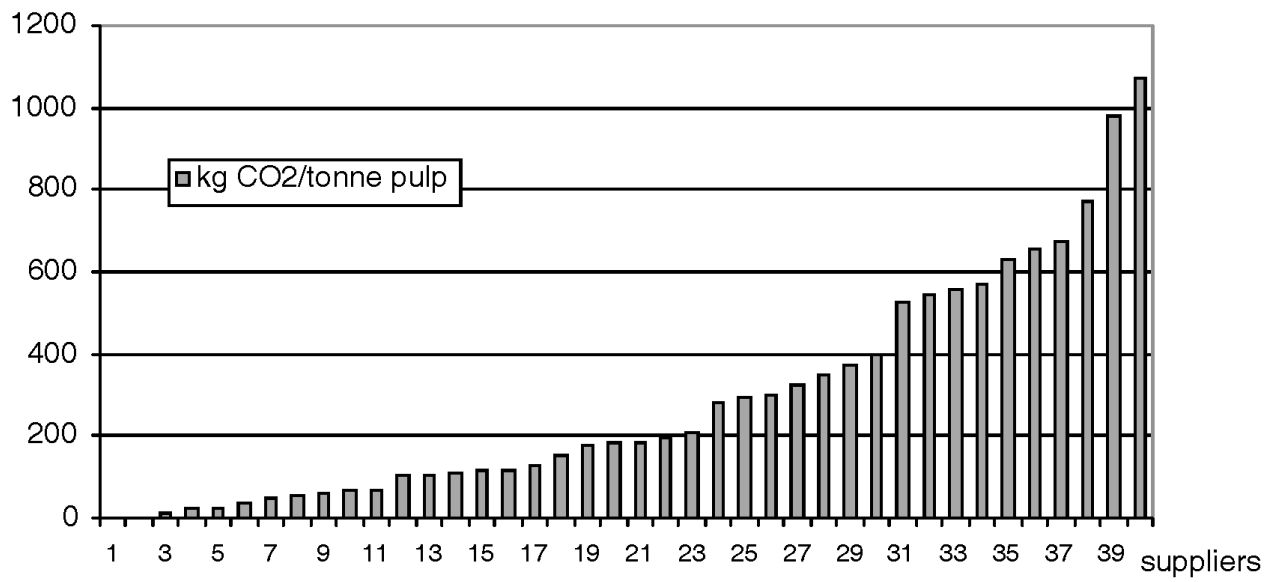

Similar types of variations have been found in various reports on, for example, data quality in LCA but also in other fields, as the following examples illustrates:

- Hunt [7] examined variations in data for similar industrial processes in environmental databases used for making LCA studies. Hunt reports that emission data can vary by $\pm 40 \%$ for similar type of industrial processes. For energy data, the variation is more modest, up to $\pm 15-20 \%$ for similar processes.

- In a study by Von Bahr et al. [8], the environmental performance of five cement plants was compared. It was found that although the plants produced more or less the same final product, there were significant differences in the level of $\mathrm{SO}_{2}, \mathrm{NO}_{\mathrm{x}}$ and dust emissions per tonne product.

- Norwegian statistics on buildings exhibit great variation in their energy consumption. For example, the energy consumption for office buildings ranges from $100 \mathrm{kWh} / \mathrm{m}^{2}$ to $650 \mathrm{kWh} / \mathrm{m}^{2}$ and for schools from $90 \mathrm{kWh} / \mathrm{m}^{2}$ to $370 \mathrm{kWh} / \mathrm{m}^{2}$. The statistics also show that the energy consumption does not depend on the age of the building [9].

- Sennett [10] described how automation in a bakery led to the production of a huge amount of waste and blackened loaves, compared to the 'old' days of when baking was more manual and waste-free. Computerised baking with sophisticated, reconfigurable machines sometimes fails to gauge accurately the strength of the rising yeast or the actual colour of the loaf. He observed that with flexible work-time schedules, people often go home just as disaster is coming out of the oven. It is then easier to throw away the spoiled loaves, reprogram the computer and start all over. 
None of the authors cited in the examples have environmental performance as a consequence of organisation as their main concern. Examples like the Scott Paper case are well known in the LCA research community, and the great variation of data is in that circle often seen as a LCA data quality problem. However, the suggestion here is to view the variations as telling symptoms of different managerial approaches to, for example, environmental management, maintenance, production management and technology choice.

\section{Review of research on environmental performance: identification of a research gap}

So far, it seems that relatively little work has examined the influence of management on environmental performance, although research on environmental management and environmental systems analysis has been going on for more than a decade. There is a gap between these two bodies of knowledge, rooted in the different academic disciplines. On a general level, Latour [11] describes the gap between studies of humans and culture and studies of nature and artefacts as the 'great divide'.

Environmental science and engineering use methods such as life cycle assessment, material flow assessment and environmental indicators to describe the environmental performance of a product system, the industrial system in a region or a company. However, the focus in these studies is usually on the environmental performance of technical systems. They rarely take account of the organisational dimension (e.g. [12]). Similarly, the endeavour to achieve greater 'eco-efficiency' can be characterised as the promotion of eco-efficiency via successful examples (e.g. [2,13,14]), not by the systematic analysis of the necessary organisational and managerial conditions. Research into eco-efficiency (e.g. [15]) is mostly concerned with the consistency and credibility in company environmental reporting.

On the management side, environmental management research has not seriously addressed the (biophysical) environmental impacts [16-18]. The reason for this is that management research focuses mostly on environmental issues from the perspective of human perceptions, decisions and actions, without evaluating the environmental effectiveness of the strategies and practices employed in industry. Hence, studies have, e.g., identified national differences in the focus on environmental work: e.g., an international comparison revealed that there is more emphasis on undertaking technical measures in Switzerland, whereas Swedish industry tends to focus on environmental management systems and environmental reporting (e.g. [19]). However, as such studies have not addressed the environmental performance of the companies, the effectiveness of these different management approaches is not known.

Nevertheless, some studies exploring environmental performance in relation to organisational and managerial issues can be found. Many of them attempt evaluating the environmental benefits of environmental management systems (EMSs) but there are also studies that look into, for example, environmental product development and international environmental treaties. When reviewing these studies, attention was given to their methodological approach to linking environmental performance to organisational aspects. 
In a study of four generation business telephones, Al-Okush et al. [20] concluded that Design for Environment guidelines did not have as great an impact on the environmental performance as may have been desired. The fourth generation telephone developed according to state-of-the-art DfE guidelines performed worse than the third generation telephone in several aspects. Changes in strategies for manufacturing, purchasing and product development were not reflected in the DfE guidelines; this may explain why they were not effective.

In their review of seven studies evaluating EMS' impact on environment, Schylander and Zobel [21] were not able to give a conclusive answer regarding the environmental effects of EMSs. They also point out that the methodology used in most EMS evaluations is unsuitable for determining whether or not EMSs really are a positive phenomenon from an environmental point of view. Most of the EMS evaluations look at the change of environmental performance once an EMS has been implemented. With such an evaluative strategy, it is impossible to tell if an improvement is caused by the EMS or by for example new laws or changed production. Moreover, it does not measure whether EMS firms have a better performance than non-EMS firms. The recommended evaluating strategy should be comparison of the development of environmental performance in EMS firms with that in similar non-EMS firms before and after implementation [21,22].

Few management studies have investigated the impact on the natural environment of any other organisational characteristics than those explicitly related to environmental management. Among those that have addressed the environmental implications of some other characteristics, one finds studies on lean production [23] and foreign ownership [24]. Unfortunately, these studies have not elaborated on the mechanisms that link specific organisational characteristics with specific material outcomes.

Studies investigating the relationship between economic and environmental performance can be found in the field of econometrics. A flaw in many of these studies is the use of awkward measures of environmental performance. For example, attempts to correlate changes in economic parameters over time to $\mathrm{pH}$ in pulp mill effluent (NB: $\mathrm{pH}$ ought to be a 'constant') or to dependent environmental parameters (such as BOD and TSS) as if they were independent have been found in the literature (e.g. [25]). If the parameters used are not wrong, they are often lacking (e.g., the constant, yet inadequate use of Toxic Release Inventory data as a measure of overall environmental performance in US studies). Thus, studies on the links between economic and environmental performance are confusing and inconclusive, partly due to poorly operationalised measures of environmental performance.

Regime theory is a research field concerned with, among other things, international environmental treaty making, and environmental effectiveness of treaties is discussed to some extent in this field. Regime scholars distinguish between institutional effectiveness, indicating that a regime is operating in some sort of agreed-upon fashion by its members, and environmental effectiveness, which connotes an improvement in the quality of the natural environment through the actions of the regime [26]. In the review of the research on the effectiveness of environmental regimes, Cioppa and Bruyninckx [26] observed that one of the shortcomings within much of the literature is a confusing tendency not to distinguish between institution and environmental effectiveness. Their closer examination showed that the focus is more on the formation and operation of environmental institutions and less on their ability to actually deliver environmental protection. 
While there are a number of research traditions in technology management and organisations and technology, they have not addressed the link with the natural environment. Traditional technology management studies the economic and organisational aspects of technology development and adoption [27]. A number of approaches under the heading of 'social studies of technology' have attempted to link technology development and use more firmly into their socio-cultural context. Most ambitiously, actor-network theory has attempted to apply a symmetric approach to human and non-human actors (e.g. technology and nature). Yet even in this field, there is little research on the natural environment, and so far none, it seems on environmental performance in an industrial context (see the overviews of Murdoch [28] and Law [29]).

\section{EAO addressing a blind spot in research}

The previous section shows that there is very little research concerning the study of environmental effectiveness of management in firms and industrial production and consumption. Although some relevant work has been identified in various fields (e.g., environmental management systems, econometrics and international policy), the environmental assessment theme is not a dominant one in any of these fields. Moreover, the way environmental performance is modelled and then, in turn, related to organisational processes and features is often unsatisfactory and in need of development.

The concept of environmental assessment of organising attempts to address the identified research gap. It represents a field where the study of organisations is linked with the study of their interaction with the natural environment. The aim is to develop an understanding of the role of organisational processes and management for environmental performance. Such an understanding could contribute to more environmentally efficient management in industry and provide insights relevant for developing environmental policies such as IPPC (Integrated Pollution Prevention and Control) and IPP (Integrated Product Policy).

A few words about the naming of the EAO concept are in place. Environmental assessment, I hope, is straightforward. The word organising was chosen instead of organisation. One of the reasons is that organisational theorists mean that people are constantly involved in the act of organising, whereas the term 'organisation' does not convey the constant social construction that 'organising' implies. Another reason is that many (environmental researchers) tend to associate 'organisation' with organisational structure, only. However, there is more than structure to organising, e.g. routines, learning process, etc. A third reason is that for instance product chains consist of many organisations (firms, etc.) yet it can be viewed as one organised entity, namely the product chain.

\section{Theoretical foundation and methodological approach of EAO}

Put simply, EAO is the combined study of the organising features and the environmental aspects of a technical system. By comparing different cases and by keeping the 
technology (relatively) similar in these comparisons, relationships between organising features and environmental aspects can be discerned.

How the organisational dimension is to be studied and described is probably a more difficult methodological issue than how to tackle the environmental dimension. Environmental parameters could be based on LCA or on site-specific environmental indicators. In reality, a small set of selected parameters will often serve as proxies for overall environmental performance. Environmental system studies (life cycle assessment, material flow analysis, etc) from the past decade are a source of essential information and knowledge for the choice of environmental parameters in EAO studies. Organisational 'parameters', on the other hand, may include anything from size and organisational structure to governance, organisational culture and economic performance.

An additional and most important parameter for explaining organisational influence on the environment is time. Environmental performance measured over time can display trend breaks, which can be traced back to changes in the organising processes. This is an important way of identifying organisational influence on the environment. The study of changes over time is found in some of the reported studies but not all of them. Moreover, the measurement of environmental performance over time allows the calculation of environmental pay-back time for material investment and changes to the technical system.

At least two approaches can be used for linking environmental performance to organisational processes. I call them the correlational and the relational approach. In the correlational approach, collection of environmental data is done relatively independently from that of organisational data. Various statistical methods are then used for the subsequent coupling of these two types of data. The relational approach builds on a closer study of the handling of the technology as well as the activities and the discourse related to it and its performance. Organisational data is the rich material resulting from following and documenting activities involved in the handling of the technology and material flows.

Statistical studies using the correlational approach can be used to indicate where relationships between the environmental and organisational dimensions are found. However, the correlational approach can only indicate relationships without uncovering causalities. Nevertheless it can be useful for identifying areas for further studies. Detailed fieldwork in line with the relational approach that involve the parallel recording of environmental, technical and organisational characteristics can open the 'black boxes' of relationships and causalities.

EAO puts into practical application theories developed within sociology of technology and organisational theory, particularly those concerning (socio-technical) hybrid networks developed by Latour [11] and action nets by Czarniawska [30]. The hybrid network is an interesting concept for EAO since it is a network not only of people, but also includes technology and nature. Action nets are also interesting since this concept denotes networks that are less dependent of its actors and more on the type of activity being organised. For example water production is a relatively stable industrial activity with its own set of organising patterns even if individual actors and even companies may change over time. 


\section{Results from some EAO-oriented projects}

EAO is presently being tested at my university department. The correlational approach was used in a study of environmental and financial performance of oil companies in the USA. The relational approach is tested in a second study, on housing management in Göteborg, Sweden.

In a Master's thesis project by Agrawal [31] the financial performance of all US oil companies was evaluated in relation to their environmental performance. Agrawal evaluated the trends in environmental performance in a number of ways with regard to the type of firm, size, market sector, financial performance and stock price. The only factor that consistently showed correlation with environmental performance was stock price. Agrawal showed that the financial performance (as stock price) was correlated to the existence of environmental reports and brochures and not to the companies' environmental performance (amount of emitted pollutants relative production capacity). A portfolio analysis indicated that those companies that provide additional information to the public about environmental performance beyond what is required by the EPA consistently do better than those firms that do not (see Figure 2).

Figure 2 Companies that provide additional information to the public about environmental performance beyond what is required by the EPA consistently do better on the stock exchange than those firms that do not

Portfoilio Performance Jun 1992 - De c 2000
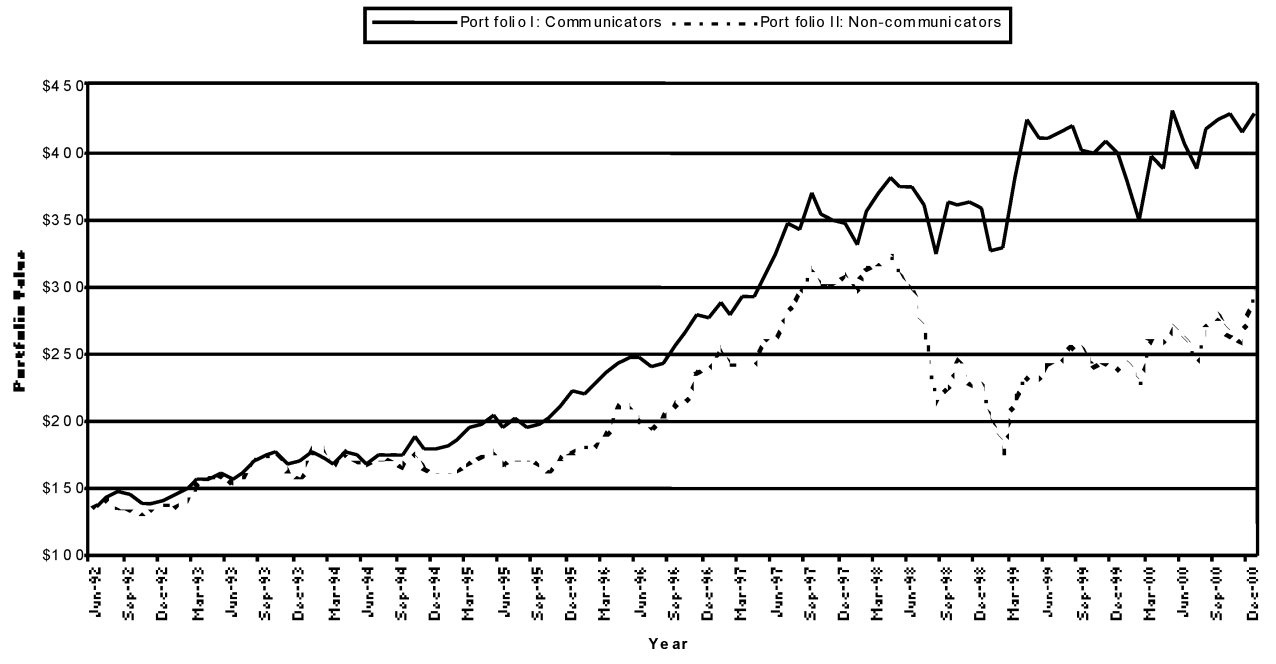

Though the portfolio value of firms that communicate more environmental information is higher than those that do not communicate information, their environmental performance has been consistently lower since April 1994 [31]. This can be seen in Figure 3. The study indicates that the appearance of environmental management and communication is more important than actual environmental performance when it comes to the overall valuation of firms. 
Figure 3 Firms that provide additional information (e.g. environmental reports, brochures, and environmental websites) to the public about environmental performance consistently produce more waste than those who only publish what is required by the US-EPA

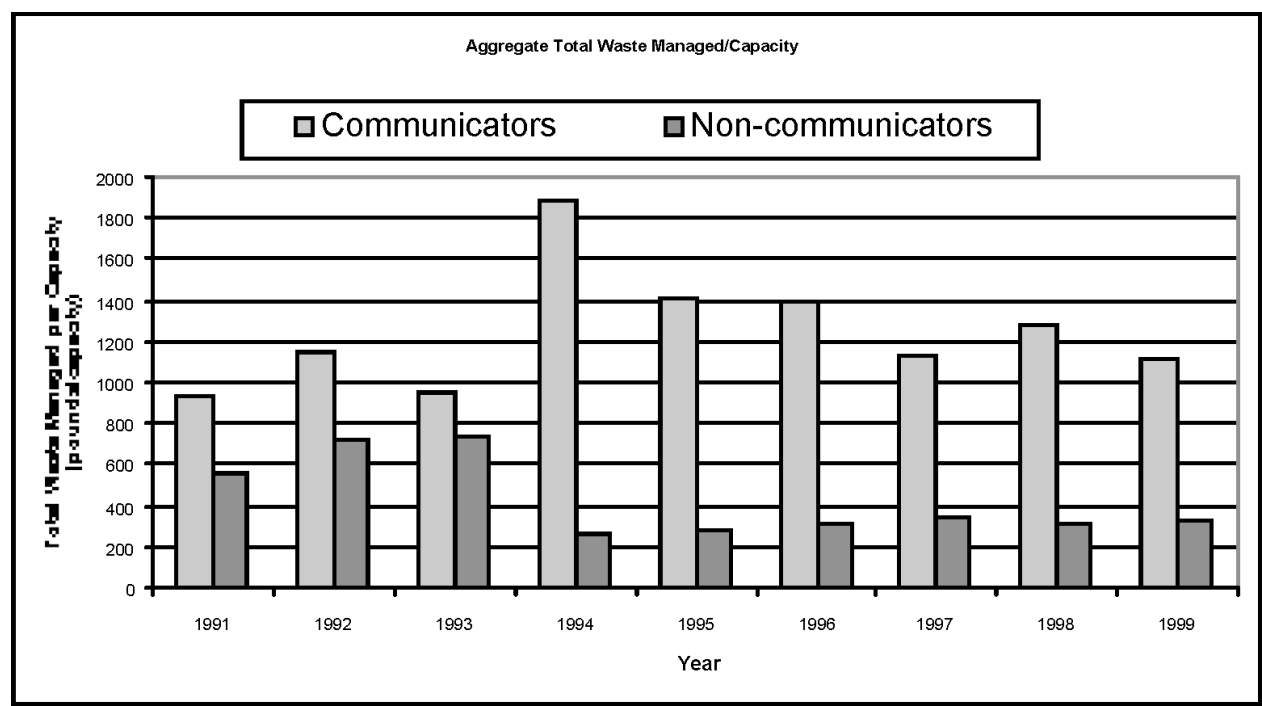

In Brunklaus' doctoral project, apartment buildings of a similar kind but managed by different property managers are evaluated with regard to their environmental performance. A basic methodology is described by Brunklaus and Baumann [32]. The apartment buildings in the case study consist of a local type called 'landshövdingehus' (county governor houses), consisting of a first storey built in stone and next two storeys built of wood. Preliminary findings show that housing companies differing with regard of ownership do display different levels of environmental performance. Consumption levels of for example water and energy differ in the order of $25 \%-33 \%$ between apartment buildings owned by two different organisations (see Figure 4) even if the buildings are of the same type and age. It is difficult to explain the difference with the behaviour of the people living in these buildings or with different local climates since the buildings are located in the same neighbourhood and have apartments of approximately the same size and thus more or less the same type of inhabitants. Care has been taken in the choice of studied buildings so that the main difference between the buildings is found in the arrangements concerning management and ownership of the buildings. Company documents, annual reports complemented with observation of the buildings and interviews of e.g. janitors, maintenance managers and CEOs has been used to produce a multi-layered chronology describing the maintenance and renovation history of each building and the organisational changes within the two companies. The material reveals that there are different patterns of organising around the buildings. The building belonging to a HSB housing association exhibits up-keep and maintenance activities that are flexibly planned and adapted to the 'needs' of the building, whereas up-keep and maintenance in the Familjebostäder buildings follow cyclic and rather rigid maintenance plans used for all buildings in their building stock. In addition to the maintenance plans, which have been used for more than 30 years, Familjebostäder have attempted to make operations more customer-oriented. One 
consequence of this is the increasing time spent on e.g. gardening around the apartment building. Results so far indicate two organisations of which one centres on the 'needs' of the building, the other more on the needs of the tenants and where the one centring on the building achieves better environmental performance. A more detailed description of this case is found in Brunklaus [33].

Figure 4 Energy use and water use in three apartment buildings (HSB Svärdsliljan and Familjebostäder Svärdsliljan \& Jordrevan). Consumption levels differ between $25 \%$ and $33 \%$ even if the buildings are of the same type and age [33]
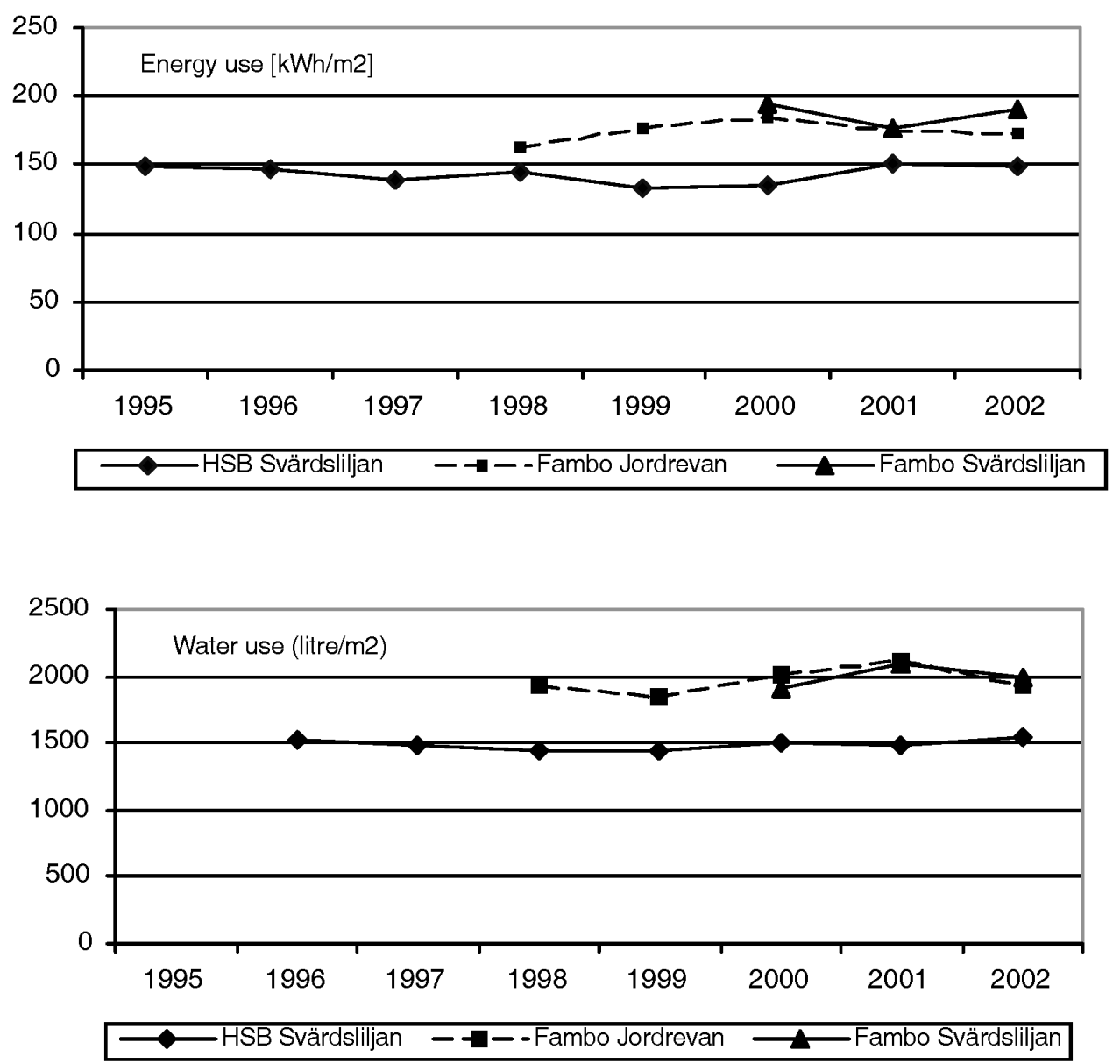

These studies support the notion that organising processes influence environmental performance and that both the relational and correlational approaches are feasible. They have also shown that environmental data were possible to find or reconstruct from economic data, which requires a good rapport with the investigated organisations. In one case, a data series stretching more than 30 years back in time has been possible to assemble. 


\section{Call for work}

The different research fields surveyed earlier (e.g., environmental management systems, econometrics and international policy), display some similarities but also differences in the way environmental performance is measured and explained. A methodological framework for EAO ought to encompass a coherent set of evaluative strategies and techniques. Methodology development would certainly benefit from an exchange between these different fields.

The development of a practical EAO methodology requires the parallel development of guidelines for describing the organisational dimension and principles for measuring environmental performance. For this purpose, case studies are particularly important for the study of EAO because they will enable the identification of the complex mechanisms that link organisational characteristics to specific environmental outcomes, but they will also provide us with the means for further developing and documenting EAO methodology.

A number of different EAO studies are possible. A criterion that guides the research design is that each case (company or product chain) in a comparison should produce the same type of product. This is because EAO seeks to understand how industrial organising relates to environmental performance. In this regard, EAO draws on the same type of functional comparison that is also used in the LCA approach.

A place to look for case studies is in sectors where there are several companies competing on the same market, operating for example on different scale, with different competitive approaches or under different types or ownership. Possible cases to study could be comparison of bakeries (operating on different scales and with different degree of automation), taxicab companies, silicon chip producers or property companies, as in the Brunklaus' example. These cases would typically focus on the organising within the company. Organising features that could be studied are the influence of for example automation, standardisation, introduction of quality management schemes and different types of ownership (e.g. private, state and public ownership) and take-overs (i.e. changes) in ownership. By combining environmental indicators that are company-specific and life-cycle-based, it is possible to examine to what extent the overall environmental performance is decided directly by the activities and decisions in a company or indirectly by other utility companies or other companies in the product chain. Another type of case studies concerns the organising of product chains. With increasing collaboration in e.g. supply chain collaboration and during product development with suppliers, the whole of the product chain must be looked at. With these type of case studies it could be possible to study the effects of outsourcing, the influence of mergers, centralisation/decentralisation, evaluate fair trade schemes or ecolabelling schemes or producer takeback schemes, among other things.

Studies with a correlational approach would draw heavily on statistical analysis, whereas studies with a relational approach could draw on theoretical and methodological resources from the social studies of technology (e.g. [34,35]) and related organisational studies [36,37].

The work to assess the influence of organising and management practices on the environment is certainly not a sinecure. A number of challenges need to be overcome. One is that EAO requires an interdisciplinary approach, more particularly the 
combination of expertise within environmental assessment (LCA, MFA etc.) and social sciences, in particular organisational theory. Such a combination is not commonplace among scholars, and given the 'great divide' not easy to achieve. Another concerns the access to data. Some of the shortcomings in reported studies can be related to insufficient data. However, careful choice of case studies could provide a detour around this problem. Furthermore, measuring the environmental performance of various organising features in complex industrial networks again requires a careful choice of case studies. Otherwise findings will be confused by the presence of too many variables influencing environmental performance. However, given the sizeable impact of industrial production and consumption has on the environment, my hope is that at least we reach better methods and that more studies exploring the links between organisations and the environment are attempted. As we now have reached a point in time when a sizeable body of knowledge stemming from environmental systems studies of technical systems exist, it ought to be possible to start adding an understanding of the organising processes that run it to it. With such an understanding, implementation of environmental strategies in industrial organisations and public policy making stand a better chance to be not only environmentally effective but also organisationally efficient.

\section{Acknowledgement}

Valuable feedback has come from several sources. Many thanks to PhD Eva Heiskanen (Helsinki School of Economics, department of Organisation) with whom I discussed the concept early on and who contributed with many inputs to the reference list. Later, comments and questions received in relation to two presentations have contributed to the refinement of the paper. The presentations were given at:

- The special symposium on Business and Industrial Ecology, part of the Business Strategy and Environment conference, September 15-16, 2003, in Leicester, UK.

- The seminar group on Organising Action Nets led by Prof. Barbara Czarniawska at the Gothenburg Research Institute, November 4, 2003, School of Economics and Commercial Law, Göteborg University, Sweden.

\section{References and Notes}

1 Azar, C. and Lindgren, K. (1998) Energiläget 2050, Report 4894, Swedish Environmental Protection Agency, Stockholm.

2 Hawken, P., Lovins, A. and Lovins, H (1999) Natural Capitalism. Creating the New Industrial Revolution, Little, Brown \& Co., New York.

3 Zackrisson, M., Enroth, M. and Widing, A. (1999) Miljöledningsystem - papperstiger eller kraftfull verktyg?, IVL Rapport B 1351, IMT, Stockholm.

4 King, AA. and Lenox, MJ (2000) 'Industry self-regulation without sanctions: the chemical industry's Responsible Care Program', Academy of Management Journal, Vol. 43, No. 4, pp.698-716.

5 Kuisma, M., Lovio, R. and Niskanen, S. (2000) Hypoteesejä ympäristöjärjestelmien vaikutuksista teollisuus-yrityksissä. (Hypotheses on the impact of environmental management systems in industrial firms), Helsinki: Finnish Environment 486. 
6 ENDS (1992) 'Scott ltd cleans up paper chain', ENDS Report, No. 214, p.17, Environmental Data Services (ENDS), London, UK.

7 Hunt, RG. (1992) Twenty-two Years of Life Cycle Analysis: What Have we Learned?, Presentation June 2 1992, Danish Technological Institute, Taastrup, DK.

8 Von Bahr, B., Hanssen, OJ., Vold, M., Pott, G., Stoltenberg-Hansson, E. and Steen, B. (2002) 'Experiences of environmental performance evaluation in cement industry. Data quality of environmental performance indicators as a limiting factor for benchmarking and rating', Journal of Cleaner Production, Vol. 11, No. 7, pp.713-726.

9 Enova (2002) Bygningsnettverkets energistatistikk. Årsrapport 2001, Report No. 2/02, Enovas byggoperat $\varnothing$ r, Bergen, Norway.

10 Sennett, R (1998) The Corrosion of Character. The Personal Consequences of Working in the New Capitalism, WW Norton \& Co, New York, NY, USA.

11 Latour, B (1993) We have never been modern. [Nous n'avons jamais été modernes: Essais d'anthropologie symmétrique. 1991. Translated by Catherine Porter.] Harvard University Press, Cambridge, Mass., USA.

12 Mac, A (2001) 'When firms make sense of environmental agendas of society', Journal of Cleaner Production, Vol. 10, pp.259-269.

13 Von Weizxäcker, E.U., Lovins, A.B. and Hunter, L.H. (1997) Factor Four: Doubling Wealth - Having Resource Use, Earthscan, London.

14 Schmidt-Bleek, F (1998) Das MIPS-Konzept. Weniger Naturverbrauch - mehr Lebensqualität durch Faktor 10, Droemer Verlagsanstalt, München.

15 The EU project MEPI - measuring environmental performance in industry.

16 Heiskanen, E (2002) 'The environmental agenda in organization and management research toward interdisciplinarity?', The Journal of Transdisciplinary Environmental Studies, Vol. 1, No. 2, pp.1-15. (www.journal-tes.dk)

17 Hvid, H. and Lambrecht Lund, H. (2002) 'Sustainable work - concepts and elements of practice', The Journal of Transdisciplinary Environmental Studies, Vol. 1, No. 2, pp.1-20. (www.journal-tes.dk)

18 Klok, A. and Mauser, A. (2002) 'The evolution of environmental management: from stage models to performance evaluation', Business Strategy and the Environment, Vol. 11, pp.14-31.

19 Belz, F. and Strannegård, L. (1996) 'Environmental management in Sweden and Switzerland. Empirical results of a comparative study', in Ulhøi, J.P. and Madsen, H. (Eds.): Proceedings of the 3rd Conference of the Nordic Business Environmental Management Network, March 28-30, 1996, Aarhus School of Business, Aarhus, Denmark., pp.219-234.

20 Al-Okush, H., Caudill, R.J. and Thomas, V. (1999) 'Understanding the real impact of DFE guidelines: a case study of four generations of telephones', IEEE International Symposium on Electronics and the Environment 1999, pp.134-139.

21 Schylander, E. and Zobel, T. (2003) 'Environmental effects of environmental management systems: Evaluation of the evidence', Paper Presented EASY-ECO 2, The Evaluation of Sustainability EU Conference, May 15-17, 2003, Vienna, Austria. (www.sustainability.at/easy)

22 Ammenberg, J (2003) Do Standardised Environmental Management Systems Lead to Reduced Environmental Impact?, Dissertation No. 851, Linköping University, Linköping, Sweden.

23 King, A.A. and Lenox, M.J. (2001) 'Lean and green? An empirical examination of the relationship between lean production and environmental performance', Production and Operations Management, Vol. 10, No. 3, pp.244-256.

24 King, A.A. and Shaver, J.M. (2001) 'Are aliens green? Assessing foreign establishments' environmental conduct in the United States', Strategic Management Journal, Vol. 22, No. 11, pp.1069-1085. 
25 Freedman, M. and Jaggi, B. (1992) 'An investigation of the long-run relationship between pollution performance and economic performance: the case of pulp and paper firms', Critical Perspectives on Accounting, Vol. 3, pp.315-336.

26 Cioppa, T. and Bruyninckx, H. (2000) 'The effectiveness of international environmental regimes: What about the environment?', Paper Presented at the 41st Annual Convention of the International Studies Association, March 14-18, 2000, Los Angeles, CA, USA. (www.ciaonet.org/isa/)

27 Kemp, R. (1994) 'Technology and the transition to environmental sustainability. The problem of technological regime shifts', Futures, Vol. 26, No. 10, pp.1023-1046.

28 Murdoch, J. (2001) 'Ecologising sociology: actor-network theory, coconstruction and the problem of human exemptionalism', Sociology, Vol. 35, No. 1, pp.111-133.

29 Law, J. (2002) Actor-network resource: thematic list. (http://www.comp.lancs.ac.uk/ sociology/ant.html\#ani).

30 Czarniawska, B. (2000). 'Att studera management som skapande och återskapande av handlingsnät', (To study of management as creation and re-creation of action nets.) Nordiske Organisasions Studier, Vol. 3, pp.5-24.

31 Agrawal, P. (2001) Development of a Conceptual Framework to Study the Relationship Between Environmental and Financial Performance, MSc thesis, Massachusetts Institute of Technology/Chalmers University of Technology, May 2001.

32 Brunklaus, B. and Baumann, H. (2001) 'Environmental assessment of housing management with LCA and time series', 1st International Conference on Life Cycle Management, Copenhagen, August 27-29, 2001.

33 Brunklaus, B. (forthcoming 2004) Licentiate thesis, Environmental Systems Analysis, Chalmers University of Technology, Göteborg, Sweden.

34 Callon, M. (1986) 'Some elements of a sociology of translation: domestication of the scallops and the fishermen of Saint Brieuc Bay', in Law, J. (Ed.): Power, Action and Belief: a new Sociology of Knowledge? Sociological Review Monograph, Routledge and Kegan Paul, London, Vol. 32, No. 196-233.

35 Latour, B. (2000) 'When things strike back: a possible contribution of 'science studies' to the social sciences', British Journal of Sociology, Vol. 51, No. 1, pp.107-123.

36 Joerges, B. and Czarniawska, B. (1998) 'The question of technology, or how organizations inscribe the world', Organization Studies, Vol. 19, No. 3, pp.363-385.

37 Gherardi, S. and Nicolini, D. (2000) 'To transfer is to transform: the circulation of safety knowledge', Organization, Vol. 7, No. 2, pp.329-348. 